www.mdpi.com/journal/remotesensing

Article

\title{
Melt Patterns and Dynamics in Alaska and Patagonia Derived from Passive Microwave Brightness Temperatures
}

\author{
Kathryn Semmens ${ }^{1,2, *}$ and Joan Ramage ${ }^{2}$ \\ 1 USDA-ARS Hydrology and Remote Sensing Laboratory, 10300 Baltimore Avenue, Beltsville, \\ MD 20705, USA \\ 2 Earth and Environmental Sciences, Lehigh University, 1 West Packer Ave, Bethlehem, PA 18015, \\ USA; E-Mail: ramage@lehigh.edu \\ * Author to whom correspondence should be addressed; E-Mail: kalese@gmail.com; \\ Tel.: +1-215-872-3998.
}

Received: 23 October 2013; in revised form: 24 December 2013 / Accepted: 2 January 2014 /

Published: 6 January 2014

\begin{abstract}
Glaciers and icefields are critical components of Earth's cryosphere to study and monitor for understanding the effects of a changing climate. To provide a regional perspective of glacier melt dynamics for the past several decades, brightness temperatures $\left(\mathrm{T}_{\mathrm{b}}\right)$ from the passive microwave sensor Special Sensor Microwave Imager (SSM/I) were used to characterize melt regime patterns over large glacierized areas in Alaska and Patagonia. The distinctness of the melt signal at $37 \mathrm{~V}-\mathrm{GHz}$ and the ability to acquire daily data regardless of clouds or darkness make the dataset ideal for studying melt dynamics in both hemispheres. A 24-year (1988-2011) time series of annual $\mathrm{T}_{\mathrm{b}}$ histograms was constructed to (1) characterize and assess temporal and spatial trends in melt patterns, (2) determine years of anomalous $T_{b}$ distribution, and (3) investigate potential contributing factors. Distance from coast and temperature were key factors influencing melt. Years of high percentage of positive $T_{b}$ anomalies were associated with relatively higher stream discharge (e.g., Copper and Mendenhall Rivers, Alaska, USA and Rio Baker, Chile). The characterization of melt over broad spatial domains and a multi-decadal time period offers a more comprehensive picture of the changing cryosphere and provides a baseline from which to assess future change.
\end{abstract}

Keywords: passive microwave; melt; remote sensing; glacier; icefield; melt regime 


\section{Introduction}

Melt dynamics of glaciers and icefields respond to weather, and collectively over the long-term can be indicators of a changing regional climate. Glacier mass loss through melting contributes to sea level rise and affects water resources [1], making understanding changes to melt patterns on large glaciers and icefields important. Two areas of rapid change are glaciers and icefields in Alaska [2] and Patagonia [3,4]. Glaciers, consisting of coastal, temperate, tidewater, and glacierized mountain ranges, cover about $75,000 \mathrm{~km}^{2}$ of Alaska with an elevation range up to $6,000 \mathrm{~m}$ [5]. In Alaska, the average air temperature increase is on the order of $2{ }^{\circ} \mathrm{C}$ since the mid-20th century [6]. The 20th century warming coincides with glacier retreat and thinning (for glaciers ending below $1,500 \mathrm{~m}$ elevation), and stagnation (for higher elevation glaciers) found at all mountain ranges and island groups in Alaska [5]. Several studies have found that Alaskan glaciers have substantially thinned in ablation areas since the 1950s [6-8]. Berthier et al. [8] used a sequential digital elevation model analysis to determine that Alaskan glaciers lost $41.9 \pm 8.6 \mathrm{~km}^{3} \cdot \mathrm{yr}^{-1}$ water equivalent (w.e.) from 1962 to 2006 which they estimate contributed $0.12 \pm 0.02 \mathrm{~mm} \cdot \mathrm{yr}^{-1}$ to sea level rise. Area average mass balance results highlight the variability in changes across Alaska with the Western Chugach, St. Elias and Wrangell, and Coast ranges having the highest losses [8].

In addition, Alaskan glacier volume loss has contributed freshwater discharge to the Gulf of Alaska with $47 \%$ of total freshwater discharge from glacier/icefield discharge and $10 \%$ from glacier thinning/retreat. This contribution is noteworthy given that glaciers occupy only $18 \%$ of the total drainage basin area [9]. The central and southeast coastal regions contributed the most to fresh water discharge (on the order of 66\%) while the Central Coast and Copper River regions had the highest percent of runoff attributed to glacier area [9]. Changes to freshwater discharge may affect coastal ocean circulation and biogeochemical fluxes especially as a result of rapidly changing glacierized basins [9].

In the Southern Hemisphere, the Northern Patagonia Icefield (NPI) covers about 4,200 $\mathrm{km}^{2}$ with average elevation of 1,100 to $1,500 \mathrm{~m}$, and is characterized by high precipitation with steep gradients west to east, high ice velocities, and high ablation rates [10,11]. Most NPI outlet glaciers terminate on land or in lakes, with the exception of San Rafael Glacier, the lowest latitude tidewater glacier in the world [4,12]. The Southern Patagonia Icefield (SPI) covers about 13,000 $\mathrm{km}^{2}$ with an average elevation of about $1,355 \mathrm{~m}$ and consists of mainly temperate outlet glaciers discharging to glacial lakes on the east and the ocean on the west [4]. In Patagonia, average air temperature warming is between 1.3 and $2{ }^{\circ} \mathrm{C}$ in the last century [13] with a trend of increasing $0{ }^{\circ} \mathrm{C}$ isotherm elevation, while the Southern Hemisphere has warmed by $0.84{ }^{\circ} \mathrm{C}$ over $1901-2010$ period [14]. More specifically, over the past 40 years there has been a warming of about $0.5^{\circ} \mathrm{C}$ at $850 \mathrm{hPa}$ for winter and summer resulting in shifts in precipitation from snow to rain and increased annual melt [15].

While the Patagonia Icefields have been losing mass since the 1870 s, the more recent warming trends are an acceleration of longer term climate change [15] and there is substantial evidence that the icefields are shrinking at an increasing rate $[3,4,10,11,16]$. Specifically, using a time series of digital elevation models (from Advanced Spaceborne Thermal Emission and Reflection Radiometer, ASTER and Shuttle Radar Topography Mission, SRTM) Willis et al. [4] found that the Northern and Southern Patagonia Icefields (NPI and SPI) contributed $-24.4 \pm 1.4 \mathrm{Gt} \cdot \mathrm{a}^{-1}$ to sea level between 2000 and 2012, a faster rate than the previous decades (1968/75 to 2000). These estimates are corroborated by several 
other studies, including Chen et al.'s [17] study using Gravity Recovery and Climate Experiment (GRACE) data to estimate an ice loss rate of $-27.9 \pm 11 \mathrm{~km}^{3} \cdot \mathrm{yr}^{-1}$ for the entire Patagonia Icefield from 2002 to 2006 and Jacob et al.'s [18] study using GRACE to determine combined NPI and SPI mass loss of $-23.0 \pm 9.0 \mathrm{Gt} \cdot \mathrm{a}^{-1}$ between 2003 and 2011.

In this study we assess melt patterns (spatial and temporal trends) derived from passive microwave satellite Special Sensor Microwave Imager (SSM/I) brightness temperature $\left(\mathrm{T}_{\mathrm{b}}\right)$ data for large Alaskan glaciers and icefields and for the Northern and Southern Patagonian Icefields from 1988 to 2011 utilizing a new metric to determine anomalous melt. This relatively long remote sensing derived time series allows for delineation of characteristic melt patterns and a unique approach to monitoring changes in melt on these important cryosphere components. Both areas investigated (Alaska and Patagonia) are wet, coastal, mid-latitude, montane environments. Passive microwave melt detection has been successfully applied in both regions previously. SSM/I derived melt and refreeze timing utilizing $\mathrm{T}_{\mathrm{b}}$ diurnal amplitude variations (DAV) was first developed and validated for the Coast and St. Elias Ranges of Alaska [19] and was used to characterize melt regimes for southeast Alaska as Taku, Saint Elias or intermediate [20]. The Taku regime, typical of most coastal glaciers such as those of the Juneau Icefield, had a distinct melt onset followed by continuous melt throughout the melt season while the Saint Elias regime, typical of high altitude glaciers, had a melt season of daily melt and re-freeze reflected by high DAV [20]. SSM/I was also able to detect glacier snowmelt and melt-refreeze timing for predicting spring flood events within \pm 5 days at the terminus of Matanuska Glacier, Alaska [21]. Higher resolution $(12.5 \mathrm{~km})$ brightness temperature data from the passive microwave Advanced Microwave Scanning Radiometer for Earth Observing System (AMSR-E) were used to determine melt timing and characteristic melt patterns from $T_{b}$ histograms on the Southern Patagonia Icefield (SPI), finding that the melt-refreeze period was decreasing across the SPI [22]. AMSR-E was also used to determine surface melt percentages for the Northern Patagonia Icefield (NPI), with wet conditions detected by satellite corresponding to rapidly thinning areas of the icefield [3].

This paper builds upon this previous work (using the same SSM/I $37 \mathrm{GHz}$ vertically polarized channel) to provide a comprehensive analysis of both regions (Alaska and Patagonia) for a longer time frame (1988-2011), albeit at the coarser resolution $(25 \mathrm{~km})$ in order to maintain consistency. We use brightness temperature histograms to characterize the full range of melt regime patterns for each area, determine years of departure from the average (anomalies), investigate potential contributing factors (using reanalysis data), and compare melt dynamics between regions. We address the questions: Do melt regime pattern and evolution vary according to climatology, distance from coast and elevation? Can the approach of using $\mathrm{T}_{\mathrm{b}}$ histogram characterization be useful for assessing and predicting future change in melt and discharge in these areas? We hypothesize that by monitoring surface melt regimes over time a phase shift would be detectable, and of particular significance if a glacierized area changes from a cold/frozen melt regime pattern to a warm/wet one.

\section{Data and Methods}

Brightness temperatures $\left(\mathrm{T}_{\mathrm{b}}\right)$ from the Special Sensor Microwave Imager (SSM/I) on the Defense Meteorological Satellite Program satellites (F8, F11, F13) and Special Sensor Microwave Imager/Sounder (SSMIS) on F17 for the period 1988-2011 were used to construct annual and average 
$\mathrm{T}_{\mathrm{b}}$ histograms (frequency of $\mathrm{T}_{\mathrm{b}}$ distribution) for $25 \mathrm{~km}$ EASE-grid pixels [23] covering large glaciers and icefields in Alaska based on the spatial intersection with GLIMS data [24] and the glacier area in Landsat ETM+ Pan sharpened mosaics (1999 to 2003) [25] (Both GLIMS and Landsat data were used because upon visual inspection glacier areas were missing from the GLIMS dataset, thus the Landsat mosaic was used to add glacierized areas based on manual inspection of intersection of pixels with glacier area where at least half of the pixel was ice covered), and in Patagonia based on spatial intersection with GLIMS data. In Alaska, 260 EASE-grid (Northern Hemisphere projection) pixels were processed and analyzed (pixels with less than 50\% ice cover from Landsat coverage and no GLIMS data were removed from the dataset); in Patagonia, 48 EASE-grid (Southern Hemisphere) pixels were processed (16 covering the NPI and 32 covering the SPI). No additional correction was done to adjust between the different sensors (F8, F11, F13, F17) in order to avoid introducing unknown bias, and due to only minimal differences found for the majority of the pixels (on the order of $0.5 \mathrm{~K}$ and $2 \mathrm{~K}$ ) (http://nsidc.org/data/docs/daac/nsidc0032_ssmi_ease_tbs.gd.html)[23]. Coastal and mountainous pixels are most likely to have higher differences between sensors (up to $\pm 20 \mathrm{~K}$ ) which is a source of uncertainty in the dataset and a limitation in our study. We characterize coastal pixels as the unimodal/mixed category (see Figure 1 below) and focus on the other categories to minimize this limitation.

Figure 1. Generalization of melt regime pattern determined from the sum of annual brightness temperature histograms. Warm/wet pixels exhibit an asymmetric high distribution skewed to the right (\#6; red curve); in contrast, cold/frozen pixels exhibit the asymmetric low distribution skewed left (\#2; blue curve). Pixels that are cold/frozen a large portion of the year but also have some melt exhibit bimodal low distribution (\#3; green curve) while ones that have more days of melt have a bimodal high distribution (\#5; orange curve). Equal time cold/frozen and warm/wet are evenly bimodal (\#4; purple curve). Pixels with mixed or water signals usually close to the coast are unimodal (\#1; yellow curve). The thin vertical line is the melt threshold for this sensor and wavelength $(246 \mathrm{~K})$ determined from previous work [20] and (in conjunction with diurnal amplitude variations, DAV) indicates when the surface starts melting.

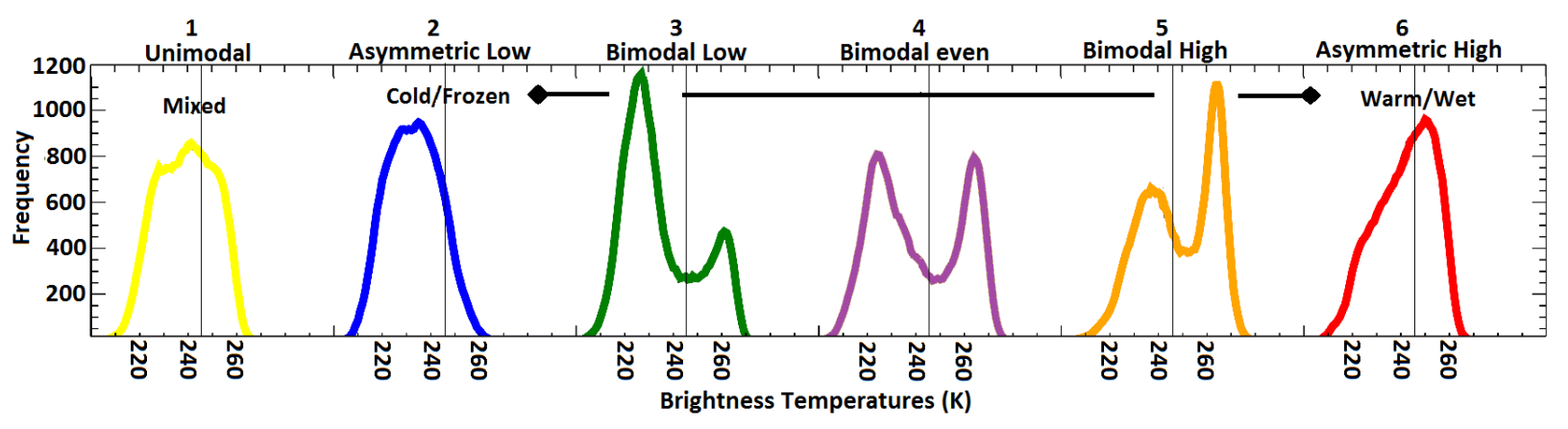

The $37 \mathrm{GHz}$ vertical polarization channel was used as it is sensitive to surface and near-surface melt and to maintain consistency with previous studies in both regions investigated here [19-22]. Daily ascending and descending $\mathrm{T}_{\mathrm{b}} \mathrm{s}$ for each pixel were concatenated, sorted by date and time, and binned for histogram analysis, producing annual $\mathrm{T}_{\mathrm{b}}$ histograms. The average frequency of each $\mathrm{T}_{\mathrm{b}}$ was calculated based on the 24 year time series producing an average $T_{b}$ histogram for each pixel. Then 
each pixel was characterized by its histogram/distribution pattern (i.e., unimodal, bimodal, asymmetric, see Figure 1). These distribution pattern categories are amended from previous work to reflect the full range of pixel $T_{b}$ characteristics in both regions by adding three new categories, mixed/unimodal, asymmetric high, and asymmetric low (see [22] and Figure 1 of this paper).

For each pixel, annual $\mathrm{T}_{\mathrm{b}}$ histograms were compared to the 1988-2011 average $\mathrm{T}_{\mathrm{b}}$ histogram to generate annual $T_{b}$ anomalies for each $T_{b}$ above and below the melt threshold $(246 \mathrm{~K})$. This is illustrated conceptually in Figure 2. Then we calculated the percentage of $T_{b}$ anomalies that were positive for $\mathrm{T}_{\mathrm{b}} \mathrm{s}$ above the melt threshold $(246 \mathrm{~K})$ and the percentage of $\mathrm{T}_{\mathrm{b}}$ anomalies that were negative for $T_{b}$ s below the melt threshold for each year. Essentially the percentage is the number of brightness temperatures that had positive anomaly (and negative anomaly) divided by the total number of brightness temperatures with values. The $246 \mathrm{~K}$ melt threshold has been previously determined and validated on the Juneau Icefield, Alaska $[19,20]$. The threshold corresponds to the dip in bimodal $\mathrm{T}_{\mathrm{b}}$ histograms because it is at this point that air temperatures have reached the melting point and emissivity rapidly increases with surface melt, therefore there are a minimum number of days with this brief transition $T_{b}$. A higher percent of positive $T_{b}$ anomalies above the melt threshold indicates a year of higher than average occurrence of warm/wet brightness temperatures while a higher percentage of negative $T_{b}$ anomalies below the melt threshold indicates a year of lower than average occurrence of cold/frozen brightness temperatures. Both positive anomalies above the melt threshold and negative anomalies below the melt threshold were considered because the $T_{b}$ signal is influenced by both wetness and temperature. Since the contribution from these factors is not easily separated it is useful to show the full range of $T_{b}$ changes. Both $T_{b}$ anomalies and percent anomalies were tracked over time and compared to air temperatures, reanalysis data, and daily stream discharge.

Figure 2. Conceptual diagram showing average histogram (thick black line) for all years compared to an individual year histogram (thin black line) and the positive (red) and negative (blue) anomaly brightness temperature frequencies.

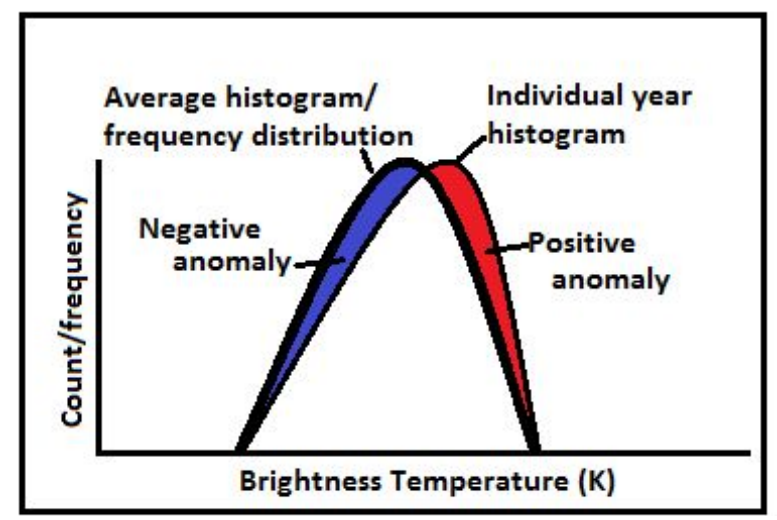

Correlations were analyzed between the percent anomalies for all pixels and years with several variables, including latitude, longitude, elevation, melt regime type, distance from coast, year, and composite sea level pressure, temperature, and relative humidity anomalies. Elevations were extracted for NPI and SPI from a $90 \mathrm{~m}$ Shuttle Radar Topography Mission (SRTM) digital elevation model (DEM) and for Alaska from a $1 \mathrm{~km}$ DEM created from GTOPO30 data from USGS EROS Data Center [26]. For Patagonia, annual composite sea level pressure, surface air temperature, and relative humidity anomalies 
were obtained from the National Centers for Environmental Prediction (NCEP) National Center for Atmospheric Research (NCAR) Reanalysis 1 project (2.5 degree resolution) [27] from NOAA's Earth System Research Laboratory Physical Sciences Division website. Carrasco et al. [28] and Rasmussen et al. [15] provide analyses of the reanalysis data for Patagonia compared to radiosonde data and find relatively good agreement starting in the late 1990s. For Alaska, the North American Regional Analysis (NARR) was used for its higher resolution (0.3 degrees $/ 32 \mathrm{~km})$. NARR is an extension of the NCEP Global Reanalysis run over North America with a high resolution Eta Model [29]. Since NARR has observational inputs similar to NCEP/NCAR Reanalysis 1, Reanalysis 1 was used in the Patagonia analysis to maintain similarity (resolution difference aside) between regions in our study.

Additionally, three case studies relating streamflow to $T_{b}$ anomalies provide an indication of the potential effects of trends. First, streamflow was investigated in the Copper River basin. As the sixth largest watershed in Alaska, the Copper River basin drains $62,678 \mathrm{~km}^{2}, 18 \%$ of which is glacier surface. With headwaters in the Alaska Range, Wrangell-St. Elias Mountains, and Talkeetna Mountains, discharge from May to October increases due to glacier runoff, changing from an average of $331 \mathrm{~m}^{3} \cdot \mathrm{s}^{-1}$ to $3208 \mathrm{~m}^{3} \cdot \mathrm{s}^{-1}$ [30]. The Copper River was chosen as a case study due to the length of the data record - daily streamflow has been collected by the USGS since 1988. For the analysis, discharge from the Copper River at Million Dollar Bridge near Cordova, AK (USGS 15214000) was obtained from the USGS National Water Information System (NWIS) and air temperature data at Cordova/Mile 13 was obtained from the National Climatic Data Center Global Historical Climatology Network (NCDC-GHCN) (station USAF 702960 WBAN 26410).

Second, streamflow was investigated for the Mendenhall River near Auke Bay, AK (USGS 15052500 NWIS, data collected since 1965) to show the relationship in a largely glacierized basin. The Mendenhall Glacier covers two-thirds of the Mendenhall River basin which has an area of about $267 \mathrm{~km}^{2}$ so the main source of water is meltwater from the glacier [31]. The analysis also included nearby air temperature from Juneau (station USAF 703810 WBAN 25309) from the NCDC-GHCN.

Third, maximum discharge for the Copper River (1988 to 2011), Mendenhall River (1988 to 2011), and Rio Baker (in Chile) (2001 to 2011) for months of typically high melt contribution was compared against the percent positive $\mathrm{T}_{\mathrm{b}}$ anomaly for the corresponding year. Rio Baker is in the Aisen Region of Chile and has a watershed area of $26,736 \mathrm{~km}^{2}$, is $170 \mathrm{~km}$ long, and has a mean annual discharge of $870 \mathrm{~m}^{3} / \mathrm{s}$. Half of its melt comes from glacial meltwater from the NPI and half is from Lake General Careera. It is Chile's largest wild river and has one of the highest flows among Chilean rivers [32]. Daily hydrological flow (2001 to 2011) for the Rio Baker en Colonia was obtained from the Direccion General de Aguas of the Ministerio de Obras Publicas, Golbierno de Chile (47.333º $\mathrm{S}, 72.85^{\circ} \mathrm{W}, 105 \mathrm{~m}$ elevation) [33].

\section{Results and Discussion}

\subsection{Melt Regimes}

While similar in terms of being wet, coastal, mid-latitude montane environments, the Alaskan and Patagonian Icefields have different melt regime characteristics (Figures 3 and 4). Alaska has a wider distribution of melt regime types ranging from the warmer/wetter asymmetric high and bimodal high distributions to the colder/frozen even and bimodal low distributions farther inland and at higher elevations. 
Patagonia regimes are characterized by more of the warmer/wetter brightness temperatures than Alaska. The Patagonian Icefields tend to have a warm/wet melt regime of asymmetric high distribution for the majority of the icefield pixels and an even bimodal distribution farther inland. The Patagonia Icefields are, in general, at lower elevations and strongly influenced by the coastal environment [4].

Figure 3. Digital Elevation Model [26] of southern Alaska with locations of pixels analyzed in the study. Dots are the centroid of the $25 \mathrm{~km}$ EASE-grid pixels used for the $\mathrm{SSM} / \mathrm{I} \mathrm{T}_{\mathrm{b}}$ data analysis. Dot colors depict the characteristic melt regime pattern (Figure 1 colors are the key) determined from the sum and average $T_{b}$ frequencies from 1988 to 2011. Relatively warmer and wetter melt patterns are found closer to the coast.

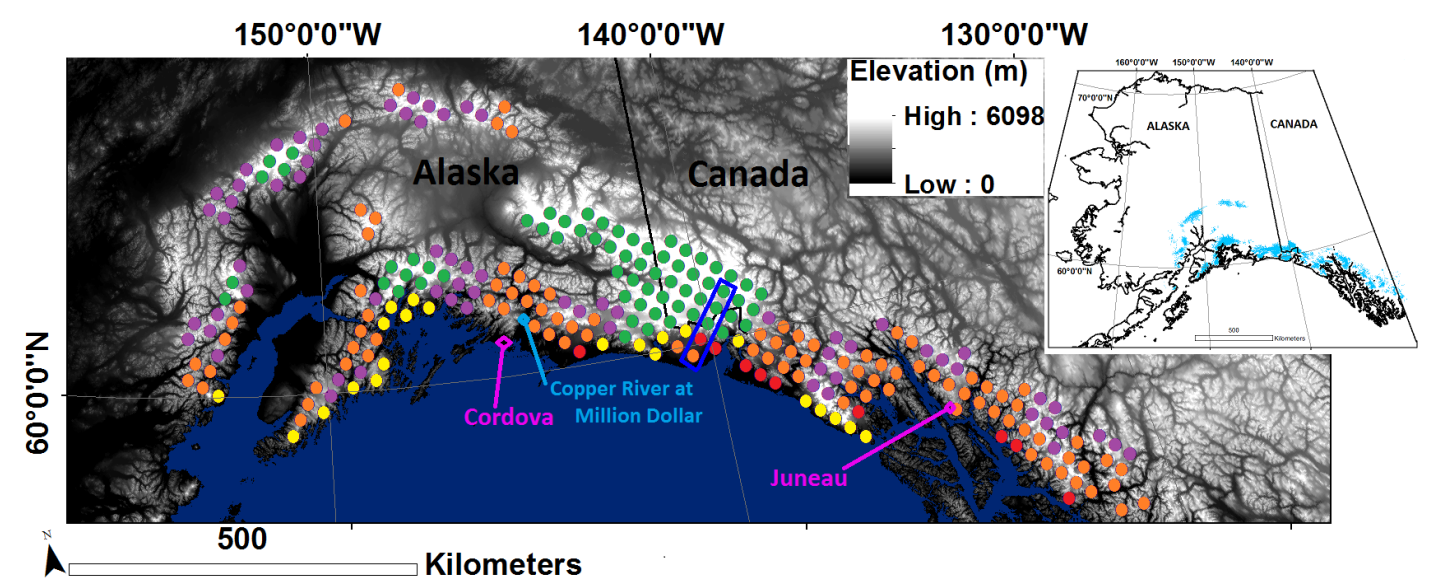

Figure 4. Digital elevation map (SRTM, $90 \mathrm{~m}$ resolution) for the Northern (NPI) and Southern (SPI) Patagonian Icefields. Dots are the center of the $25 \mathrm{~km}$ EASE-grid pixels and colors indicate general melt regime pattern from Figure 1.

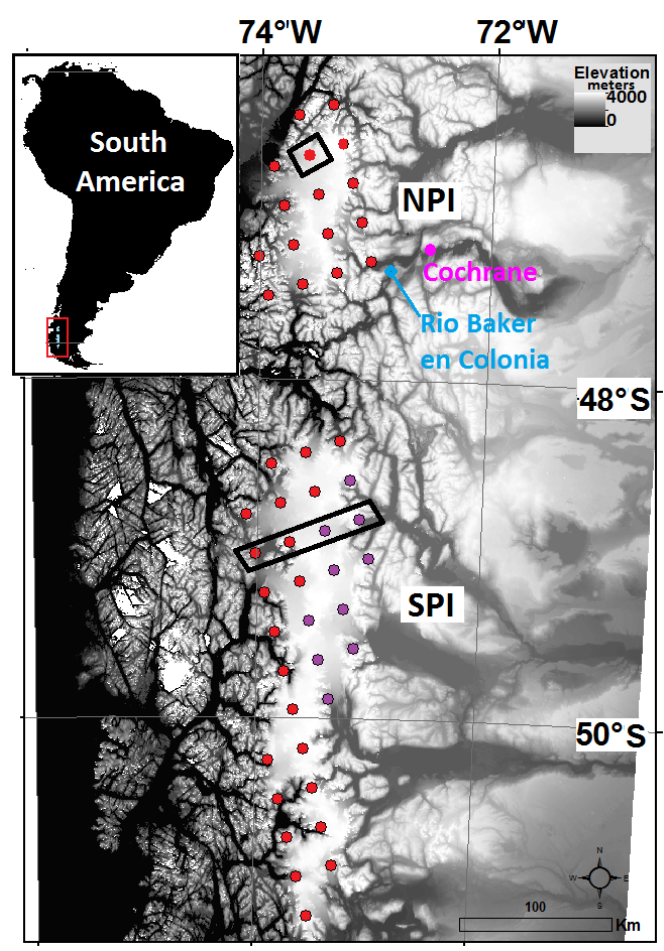




\subsection{Brightness Temperature Anomalies}

For the majority of pixels in both areas, $T_{b}$ anomalies have been positive in recent years $(2007 / 2008$ to 2011). In the transect highlighted from Alaska (Figure 5; location shown in Figure 3), the departures from average are more significant inland compared to those closer to the coast which coincides with more temperature moderation typically associated with coastal areas. In Patagonia (Figure 6; location shown in Figure 4), the seasonal components of the positive anomalies suggest that spring is the time of most departure from the norm (Figure 6 shows spring (orange line) is the most anomalous for 2011). Further, years of positive anomalies correspond to years that have a high percentage of melt days as determined from the passive microwave melt threshold $246 \mathrm{~K}$ [4].

Figure 5. Time series of $T_{b}$ histogram anomalies (difference from the average of 1988-2011) for a coast to inland transect from Malaspina to Hubbard Glaciers (see the dark blue rectangle in Figure 3 for location).

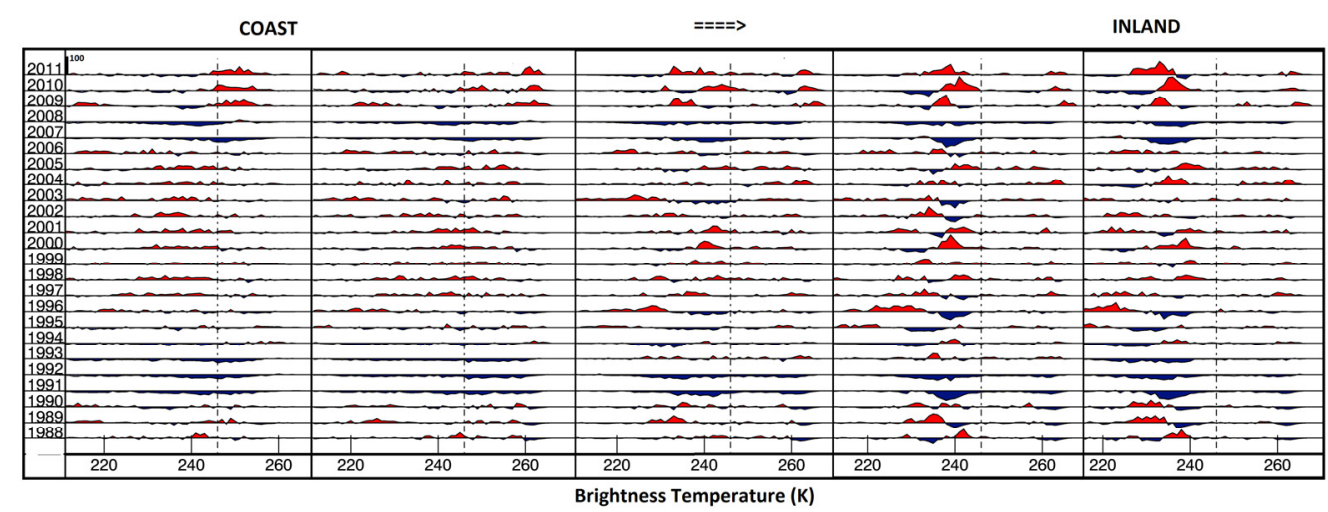

Red is a positive $T_{b}$ deviation, blue is a negative deviation. Vertical black line in each panel is the $246 \mathrm{~K}$ melt threshold. For scale, the y-axis distance between each year line is 100 (this scale measures the number of occurrences of the $T_{b}$ above or below the average frequency).

Figure 6. Time series of $\mathrm{T}_{\mathrm{b}}$ anomalies for a coast/west to inland/east transect from the SPI (first four panels) and for the pixel over San Rafael Glacier to the north in NPI (right-hand panel red outline; see Figure 4 for location).

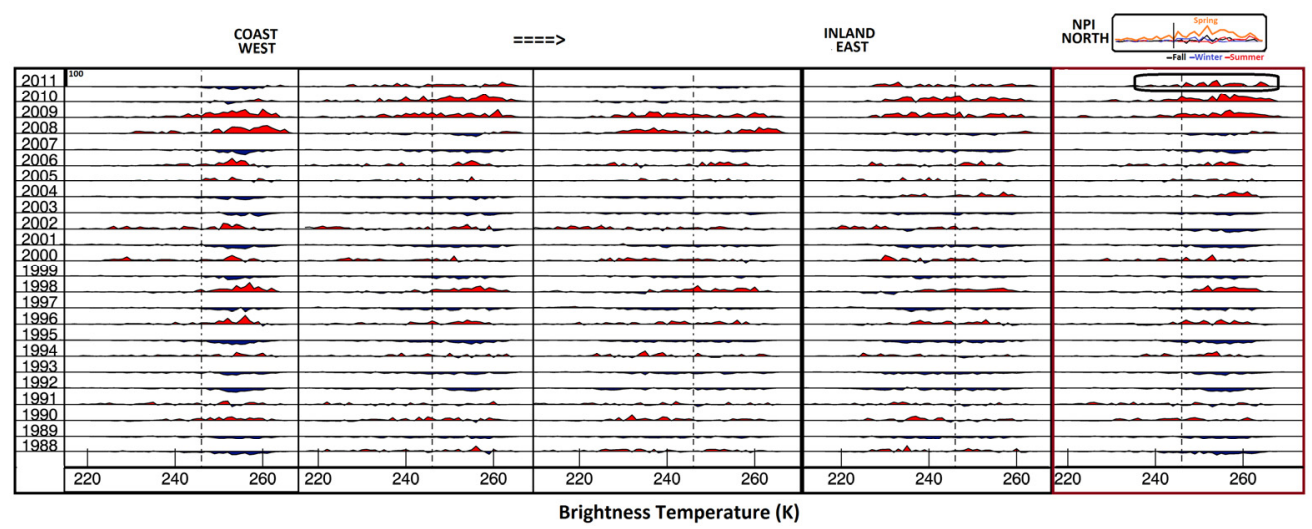

The black oval above the last panel is shows seasonal components (spring is orange; fall is black; winter is blue; summer is red). Vertical black line in each panel is the $246 \mathrm{~K}$ melt threshold. For scale, the $y$-axis distance between each year line is 100 . 


\subsection{Percent Positive and Negative Anomalies}

In Figure 7, transects investigated in Alaska and Patagonia show similar trends in the percentage of positive $T_{b}$ anomalies above the melt threshold $(246 \mathrm{~K})$ occurring higher than the average frequency (meaning more days of warm/wet $\mathrm{T}_{\mathrm{b}}$ ) and in the percentage of negative $\mathrm{T}_{\mathrm{b}}$ anomalies below the melt threshold occurring more than the average frequency (meaning less days of cold/dry $\mathrm{T}_{\mathrm{b}}$ ). Higher values of either of these measures (percent positive or negative anomalies) would suggest a change to warmer/wetter conditions with either more warm/wet brightness temperatures occurring or less cold/frozen brightness temperatures occurring. The majority of pixels behave similarly within each region. There are two distinct times of low positive anomalies - one from 1991-1993 and one from 2007-2008. For both regions, an increase in the percent of negative $T_{b}$ anomalies below the melt threshold occurs with, or immediately preceding, the increase in positive $T_{b}$ anomalies above the melt threshold. This could be due to the cold/frozen brightness temperature reflecting the change in climate and temperature first which then propagates to the warm/wet brightness temperature signal. Both positive anomalies for warm/wet $T_{b} S$ and negative anomalies for cold/frozen $T_{b} S$ increase in recent years in both regions and the more cold/frozen melt regime pattern (green) have slightly different trends than the more warm/wet melt regimes (red and orange) (Figure 7).

Figure 7. Time series (1988-2011) of the percentage of positive (and negative) $T_{b}$ anomalies above (and below) the melt threshold $(246 \mathrm{~K})$ for each year for the Alaska transect pixels (stars and solid lines) and for the Patagonia Icefield transect (circles and dashed lines) (see Figures 3 and 4 for locations). Line colors correspond to the pixel's characteristic melt regime (see key Figure 1).

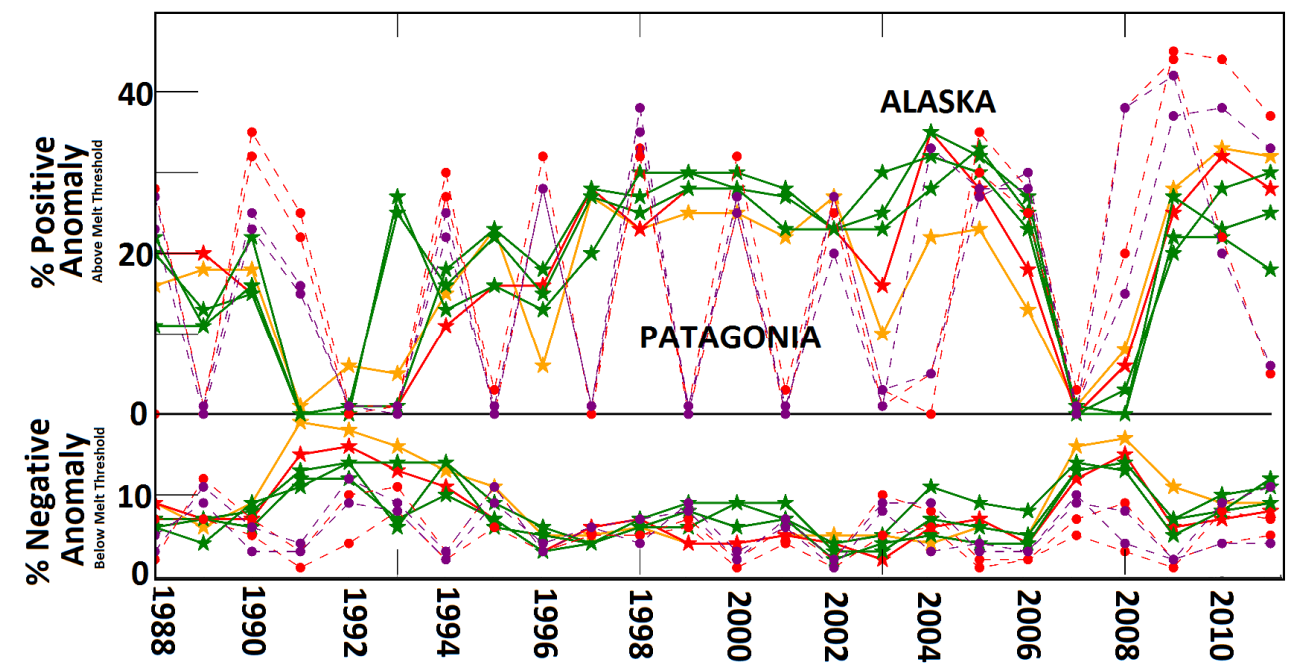

\subsection{Statistical Analysis}

To explore potential causative or correlative factors, a multiple regression and correlative analysis was conducted on each region's annual percentage of positive $\mathrm{T}_{\mathrm{b}}$ anomalies above the melt threshold $(246 \mathrm{~K})$ as well as on the annual percent of negative $T_{b}$ anomalies below the melt threshold. Positive anomalies above the melt threshold mean that there are more occurrences of warm/wet brightness temperatures while negative anomalies below the melt threshold mean there are fewer cold/frozen 
brightness temperatures that year suggesting a change to a more melt dominated regime pattern. Time series of all pixels' percent anomalies (24 data points (a percent anomaly value for each year) per pixel) in each region were assessed using multiple linear regression and latitude, longitude, elevation, distance from coast, melt regime type, composite mean sea level pressure anomalies, composite surface air temperature anomalies, composite relative humidity anomalies, and year variables (Table 1). This combination of spatial and climatological variables was investigated due to potential influence on melt characteristics. Distance to coast serves as a proxy for maritime versus continental climatology, and sea level pressure, air temperature and relative humidity are indicative of weather patterns that would result in higher melt. Higher relative humidity suggests warmer temperatures and more energy for melt. Considering relative humidity was found to improve accuracy (reducing errors and improving correlation by 10\%) in modeling melting rates of Andean glaciers [34] and therefore was considered as a variable here in addition to temperature.

Table 1. Correlation between the annual percentage of positive $T_{b}$ anomalies above the melt threshold $(246 \mathrm{~K})$ and of negative $\mathrm{T}_{\mathrm{b}}$ anomalies below the melt threshold with latitude, longitude, elevation, melt regime type, composite sea level pressure (SLP) anomaly, composite air temperature $\left(\mathrm{T}_{\text {air }}\right)$ anomaly, composite relative humidity $(\mathrm{RH})$ anomaly, year, and distance to coast (Dist2Coast).

\begin{tabular}{ccccc}
\hline & Alaska & \multicolumn{3}{c}{ Patagonia } \\
\hline & $\begin{array}{c}\text { \% Positive } \mathbf{T}_{\mathbf{b}} \\
\text { Anomaly }\end{array}$ & $\begin{array}{c}\text { \% Negative } \mathbf{T}_{\mathbf{b}} \\
\text { Anomaly }\end{array}$ & $\begin{array}{c}\text { \% Positive } \mathbf{T}_{\mathbf{b}} \\
\text { Anomaly }\end{array}$ & $\begin{array}{c}\text { \% Negative } \mathbf{T}_{\mathbf{b}} \\
\text { Anomaly }\end{array}$ \\
\hline Latitude & $\mathbf{0 . 0 6 1}$ & $\mathbf{0 . 1 7 8}$ & 0.045 & $-\mathbf{0 . 0 9 6}$ \\
Longitude & $\mathbf{- 0 . 0 3 4}$ & $-\mathbf{0 . 0 6 0}$ & 0.009 & $\mathbf{0 . 0 9 1}$ \\
Elevation & $\mathbf{0 . 0 2 5}$ & $\mathbf{0 . 1 3 1}$ & -0.027 & $\mathbf{0 . 1 6 3}$ \\
Melt Regime & $\mathbf{- 0 . 1 1 6}$ & $\mathbf{0 . 0 4 1}$ & -0.03 & $\mathbf{0 . 1 7 3}$ \\
SLP anomaly & $\mathbf{- 0 . 0 7 7}$ & -0.016 & $-\mathbf{0 . 1 1 1}$ & $\mathbf{0 . 0 9 6}$ \\
$\mathrm{T}_{\text {air }}$ anomaly & $\mathbf{0 . 0 5 4}$ & $\mathbf{0 . 0 9 5}$ & $\mathbf{0 . 1 8 7}$ & $\mathbf{0 . 1 4 1}$ \\
RH anomaly & $\mathbf{- 0 . 0 2 8}$ & $\mathbf{0 . 1 9 2}$ & $-\mathbf{0 . 0 9 6}$ & $\mathbf{0 . 0 6 0}$ \\
Year & $\mathbf{0 . 3 1 0}$ & $\mathbf{- 0 . 1 7 5}$ & $\mathbf{0 . 3 4 8}$ & $-\mathbf{0 . 1 4 3}$ \\
Dist2Coast & $\mathbf{0 . 1 4 5}$ & $\mathbf{0 . 1 9 3}$ & 0.003 & $\mathbf{0 . 1 4 3}$ \\
Multiple & $\mathbf{0 . 4 2 4}$ & $\mathbf{0 . 3 8 4}$ & $\mathbf{0 . 3 8 9}$ & $\mathbf{0 . 3 7 4}$ \\
\hline
\end{tabular}

All correlations noted in bold text are significant at 0.05 significance level with the exception of the non-bold italic numbers, which are not significant.

For Alaska, all variables together accounted for a little less than half of the variability with a multiple correlation of 0.4242 for the percent positive $T_{b}$ anomalies and 0.384 for the percent negative $\mathrm{T}_{\mathrm{b}}$ anomalies. Distance to coast was the variable having the highest correlation for both anomaly indices ( 0.145 for positive anomaly and 0.193 for negative anomaly). Year and regime type had significant correlations for the positive anomalies, meaning positive anomalies increased over time and there were more positive anomalies for warmer/wetter melt regimes. Relative humidity, latitude, and elevation had significant correlations for the negative anomalies. All correlations were significant at alpha 0.05 with the exception of sea level pressure and the negative anomalies. 
For Patagonia, all variables together accounted for more than a third of the variability with a multiple correlation of 0.389 for the percent positive $T_{b}$ anomalies and 0.374 for the percent negative $\mathrm{T}_{\mathrm{b}}$ anomalies. Only sea level pressure, temperature, year, and relative humidity were significantly correlated with the positive $T_{b}$ anomalies, while all variables were significantly correlated (at alpha 0.05 ) with negative $T_{b}$ anomalies. Melt regime, elevation, temperature, and distance to coast had the highest correlations with the negative anomalies.

From these results it is clear that distance to coast has one of the largest relative influences on the percent positive or negative $T_{b}$ anomaly among the variables considered. Distance to coast is a proxy for maritime versus continental environments and includes influences from factors such as elevation and climatology, making it a suitable proxy and metric for analysis. These results are in line with previous findings that proximity to coast and elevation are related to the duration of the melt season in Alaska [20]. For Alaska, percent anomaly was more strongly associated with regime type for the positive $T_{b}$ anomalies compared to the negative, while relative humidity was more strongly associated with the negative anomalies compared to the positive. This suggests that relative humidity has more effect on the cold/frozen $T_{b}$ frequency. For Patagonia, surface air temperature was significant for both the positive and negative anomalies, while regime type, elevation, and distance to coast were more strongly associated with the negative $\mathrm{T}_{\mathrm{b}}$ anomalies compared to the positive. This suggests that the gradient from coast to inland dominates the melt dynamics of these icefields but that overall increasing temperatures are affecting melt patterns leading to increasing occurrences of warm $T_{b}$ and wet glacier surfaces in recent years. Further, the results highlight the variable, multiple factors affecting melt dynamics in both regions.

\subsection{Discharge Case Studies}

To explore the possible effects of a year with anomalous high or low $\mathrm{T}_{\mathrm{b}}$ frequency above the melt threshold, discharge from the Copper River (near Cordova, AK) was compared to years of below average warm/wet $\mathrm{T}_{\mathrm{b}} \mathrm{s}$ (1991 and 1992 are shown for illustration, Figure 8) and to years of above average warm/wet $T_{b}$ s (2005 and 2009 are shown for illustration, Figure 8). Figure 8 illustrates the relationship: above average warm/wet $\mathrm{T}_{\mathrm{b}}$ years have earlier and higher discharge compared to below average warm/wet $T_{b}$ years. A time series of the brightness temperature and diurnal amplitude variation (DAV) (difference between the daily ascending and descending $T_{b} s$ ) shows that discharge increases dramatically after the end of the high DAV or melt-refreeze period (Figure 8 inset). After this period the snowpack/glacier surface is not refreezing at night and meltwater rapidly flows downstream.

Similarly, discharge recorded at the gauge at Mendenhall River near Auke Bay, AK, shows that years of above average warm/wet $T_{b} s$ (2002 and 2003 are shown for illustration, Figure 9) have higher peak flows throughout the year compared to years that have below average warm/wet $\mathrm{T}_{\mathrm{b}} \mathrm{s}$ (Figure 9). The peak flows are later in the summer and flashier compared to the Copper River streamflow because the majority of the water comes from meltwater from the Mendenhall Glacier. The effect of the positive anomaly $\mathrm{T}_{\mathrm{b}}$ year is consistent for both types of hydrological systems (a glacierized basin and a mixed source basin with some glaciers), a finding that instills confidence in the results and in the significance of the $T_{b}$ anomaly methodology. As with the Copper River (Figure 8), the time series of $\mathrm{T}_{\mathrm{b}}$ and DAV for Mendhenhall River (Figure 9) illustrates the importance of the high DAV period and 
its relation to the increase in discharge in the spring. Also interesting to note is the brief melt event in late winter (late February/early March) that resulted in a small spike in flow.

Figure 8. Discharge for Copper River at Million Dollar Bridge near Cordova, AK (USGS 15214000, see Figure 3 for location) for two negative $T_{b}$ anomaly years in blue (1991 and 1992) and two positive $T_{b}$ anomaly years in red (2005 and 2009) compared to the mean 1988 to 2011 (thick black line).

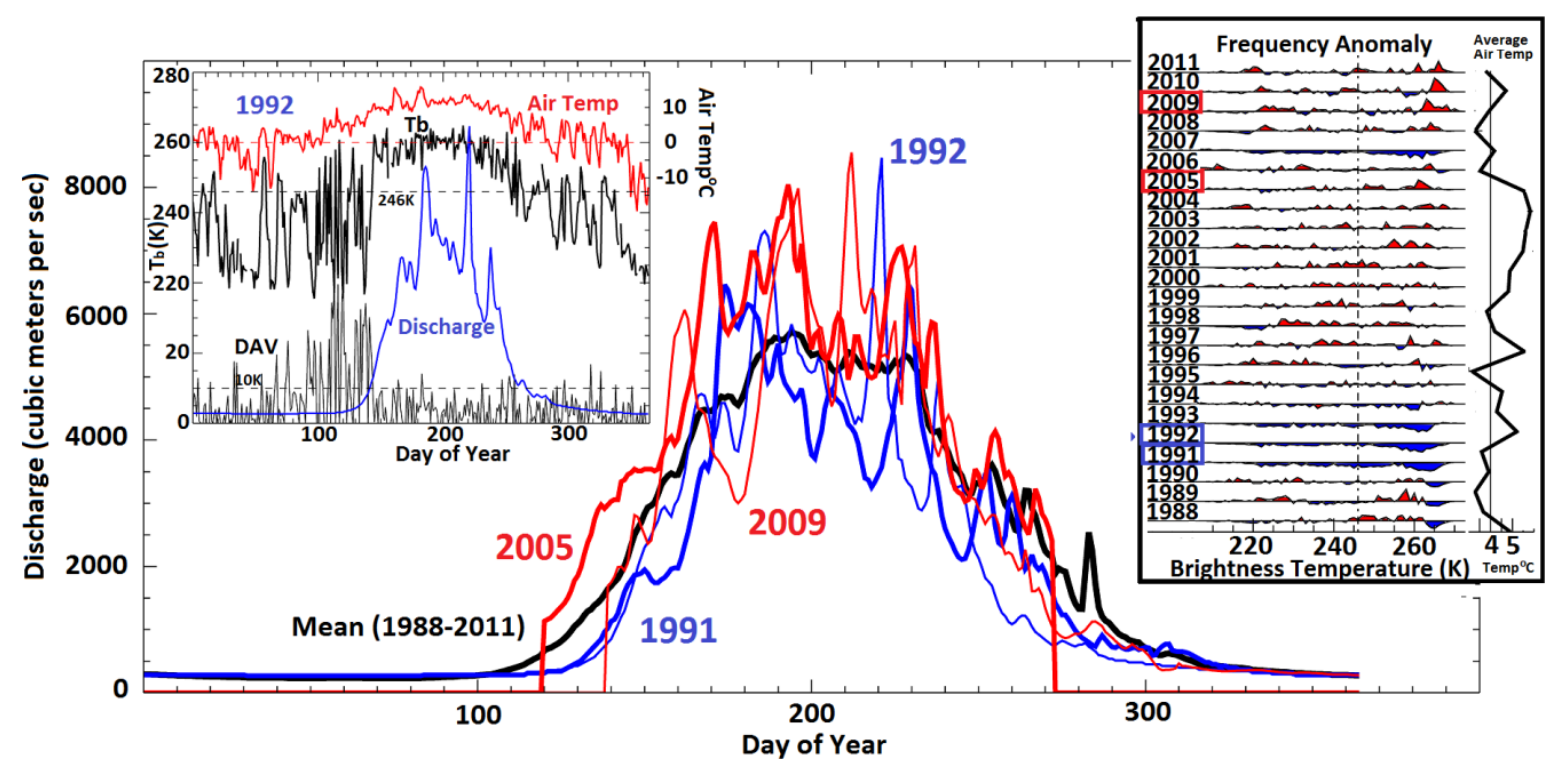

The inset at right shows the $\mathrm{T}_{\mathrm{b}}$ anomalies for the nearest pixel (average elevation $841 \mathrm{~m}$ ) and the average air temperature from Cordova (USAF 702960 WBAN 26410, $60.489^{\circ} \mathrm{N}, 145.451^{\circ} \mathrm{W}, 14.6 \mathrm{~m}$ elevation). The inset at left shows the relationship of $\mathrm{T}_{\mathrm{b}}$ (black), diurnal amplitude variation (DAV) (gray), air temperature (red), and discharge (blue). Melt thresholds are dashed horizontal lines, and the period of melt-refreeze or high DAV is denoted. The spring freshet follows the end of the high DAV period. Positive anomaly years tend to have earlier freshet and earlier and higher peak flows compared to negative anomaly years.

Figure 10 shows the relationship between discharge and years of high $T_{b}$ positive anomalies. The maximum discharge (cubic meters per second) for months that typically have highest contribution of melt runoff is plotted against the percent positive anomaly for that year. For the Copper River the maximum discharge is plotted for May, for Mendenhall August is plotted, and for the Rio Baker en Colonia February (the austral summer) is plotted. While the best linear relationship is found with the Copper River dataset (rsquared of 0.69), all sites show a positive linear relationship with higher percentage of positive anomalies corresponding to higher maximum discharge in melt dominated months.

The results from these case studies highlight the tight coupling of $\mathrm{T}_{\mathrm{b}}$, air temperature, and discharge, and underscore the utility of monitoring melt with satellite-derived $\mathrm{T}_{\mathrm{b}}$. Tracking the spatial and temporal occurrence of high or low $\mathrm{T}_{\mathrm{b}}$ anomalies may be useful for discharge, freshet, and flood monitoring. 
Figure 9. Discharge for the Mendenhall River near Auke Bay, AK (USGS 15052500, see Figure 3 for location) for two negative $T_{b}$ anomaly years in blue (1991 and 1992) and two positive $\mathrm{T}_{\mathrm{b}}$ anomaly years in red (2002 and 2003) compared to the mean 1988 to 2011 (thick black line).

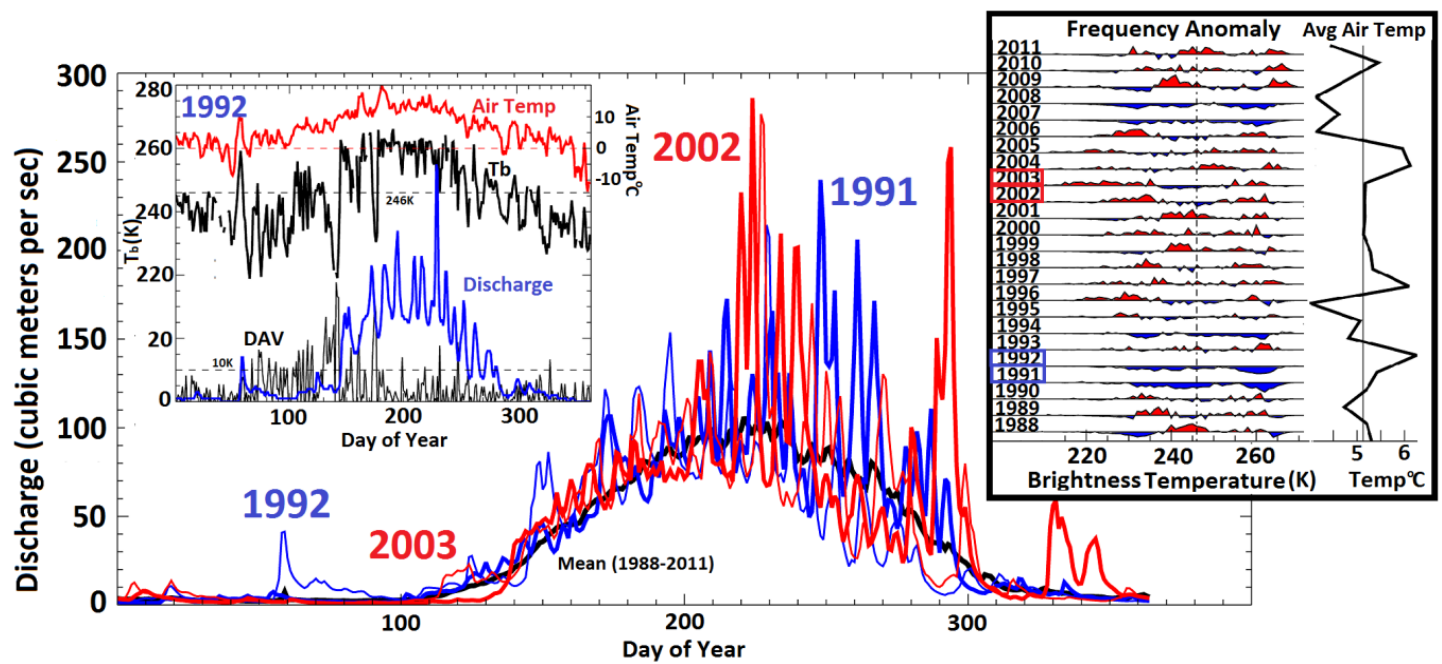

The inset at right shows the $T_{b}$ anomalies for a nearby glacier pixel (average elevation 1,358 $\mathrm{m}$ ) and the average air temperature from Juneau (USAF $703810 \mathrm{WBAN} 25309,58.357^{\circ} \mathrm{N}, 134.564^{\circ} \mathrm{W}, 7.3 \mathrm{~m}$ elevation). The inset at left shows the relationship of $\mathrm{T}_{\mathrm{b}}$ (black), diurnal amplitude variation (DAV) (gray bottom), air temperature (red), and discharge (blue) for 1992. Melt thresholds are dashed horizontal lines, and the period of melt-refreeze or high DAV is denoted.

Figure 10. Maximum discharge (cubic meters per second) for months of typical high melt runoff (May for Copper River in Alaska, August for glacial Mendenhall River in Alaska, and February for Rio Baker in Chile) plotted against the percentage of positive anomalies above the melt threshold for that year. Linear trend lines and r-squared are shown.

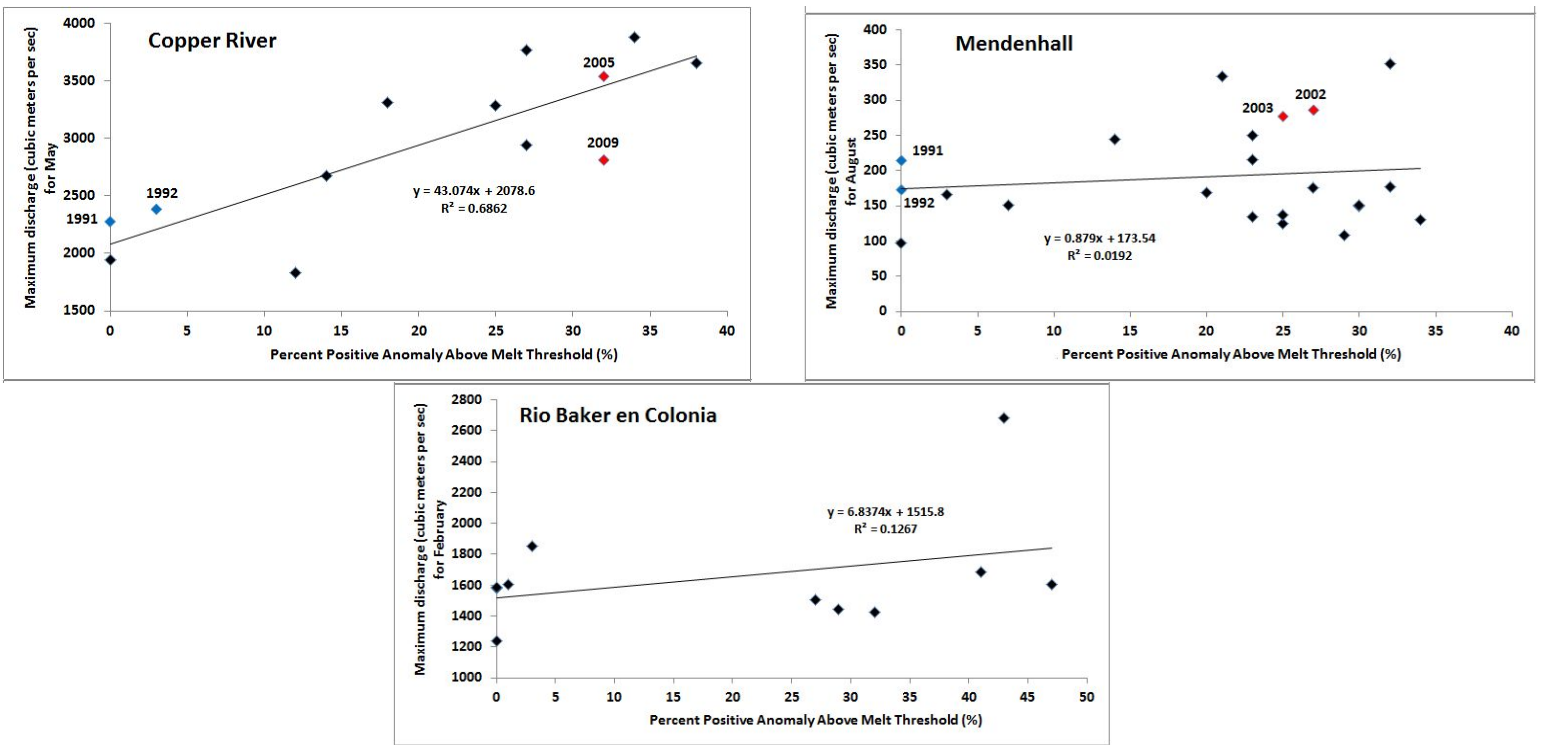

The high and low anomaly years illustrated in Figures 8 and 9 are labeled and colored red and blue, respectively, for Copper River and Mendenhall River. 


\subsection{Discussion}

Since brightness temperatures are a function of physical temperature and emissivity they are a good indication of surface and near-surface melt dynamics on glaciers and icefields. Melt regimes determined from $\mathrm{T}_{\mathrm{b}}$ histograms correspond to the general climatology of the regions investigated with more coastal, lower elevation areas exhibiting warmer/wetter environments. The coast to inland gradient of melt regime type from asymmetric high to bimodal for the SPI was also found by Monahan and Ramage [22] using higher resolution (12.5 km) AMSR-E data.

$T_{b}$ anomalies can indicate years of higher or lower temperatures and melt. For instance, two years having cold seasons of anomalous temperatures in Alaska were the winters of 2002 (warm) and 2007 (cold) [35] which were found to be positive and negative $T_{b}$ anomaly years, respectively, reflecting warmer and colder climate patterns in general for those years. Further, the largest temperature departures during these years were recorded in the continental interior Alaska with the smallest for the coastal, maritime areas. This continentality, where wider temperature ranges occur inland compared to coastal areas, is also seen in the $T_{b}$ anomaly transect results shown in Figure 5.

At high latitudes, surface temperatures (and thus melt) are influenced by atmospheric circulation patterns. This is illustrated by the 2002 warm anomaly caused by more advection of warm air due to negative sea level pressure anomalies more than $12 \mathrm{hPa}$ in the Aleutian low [35]. Further, the transition to the Pacific Decadal Oscillation's cool phase in March 2007 corresponds with cold temperature (and $\mathrm{T}_{\mathrm{b}}$ ) anomalies in the Gulf of Alaska.

For Patagonia, recent years (2007/2008 to 2011) of positive $T_{b}$ anomalies (and higher percent of melt days) coincide with icefield thinning and acceleration reported by Willis et al. [3,4]. Most of the NPI is near the freezing point making it sensitive to any air temperature change [3]. Both NPI and SPI have high mass turnover, low equilibrium line altitudes, and calving glaciers, making them vulnerable to climate change [10]. The icefields are also strongly influenced by the persistent midlatitude westerlies bringing heavy precipitation on the west side of the southern Andes [15,28].

\section{Conclusions}

Frequency distributions of passive microwave brightness temperatures from SSM/I and SSMIS were analyzed to determine characteristic melt patterns for large glaciers and icefields in Alaska and Patagonia. Melt regimes ranged from warm and wet to cold and frozen with bimodal distributions in between. Alaska had a range of melt regimes, with coastal and low elevation glacier pixels exhibiting asymmetric high distribution of warmer/wetter $\mathrm{T}_{\mathrm{b}} \mathrm{S}$ and inland, higher elevation glacier pixels exhibiting a bimodal low distribution. In contrast, the Patagonian Icefield was predominately warm and wet exhibiting the asymmetric high distribution. High bimodal/high asymmetric $\mathrm{T}_{\mathrm{b}}$ distributions are more vulnerable to regional climate change as melt is enhanced by the rising $0{ }^{\circ} \mathrm{C}$ isotherm, a finding supported by recent trends in the Patagonian Icefield.

In both areas $T_{b}$ anomalies indicated years of above or below average $T_{b}$ frequency with above average $T_{b}$ anomalies corresponding to average air temperature. Recent years showed positive $T_{b}$ anomalies, possibly associated with increasing temperatures and melt. The $\mathrm{T}_{\mathrm{b}}$ anomalies also corresponded to percent melt days in Patagonia and to discharge in Alaska with higher and earlier 
discharge associated with years having above average warm/wet brightness temperatures. Correlations suggest that distance to coast and temperature were the variables of most influence on the percent positive and negative $\mathrm{T}_{\mathrm{b}}$ anomalies.

The $\mathrm{T}_{\mathrm{b}}$ melt regime and anomaly approach show promise for monitoring future change in melt on large glaciers and icefields, and possibly for monitoring changes to discharge and peak flows in glacierized basins. Especially important would be a shift in regime from cold/frozen to warm/wet melt regime pattern. For now, the dataset provides a baseline from which to assess future change. Given the large spatial area, lack of ground data, and remote environment, using remote sensed data to detect melt on these dynamic glaciers and icefields is advantageous for understanding the cryosphere and the effects of a changing climate.

\section{Acknowledgments}

We thank the National Snow and Ice Data Center for providing EASE-Grid SSM/I and SSMIS data. Landsat ETM+ pan sharpened mosaic provided by the U.S. Geological Survey Earth Resources Observation and Science Center. NCEP Reanalysis data provided by the NOAA/OAR/ESRL PSD, Boulder, Colorado, USA. Discharge data provided by USGS National Water Information System. Air temperature data provided by the NCDC Climate Services Branch Global Summary of the Day. SRTM data provided by NASA. The manuscript was improved by thoughtful suggestions from four anonymous reviewers. Semmens was supported by NASA Headquarters under the NASA Earth and Space Science Fellowship Grant "NNX10AP14H". USDA is an equal opportunity provider and employer.

\section{Author Contributions}

K.S. and J.R. conceived the research idea. K.S. conducted the data acquisition, analysis, literature review, figures and manuscript preparation. J.R. provided resources, background methodology, and editing.

\section{Conflicts of Interest}

The authors declare no conflict of interest.

\section{References}

1. Barnett, T.P.; Adam, J.C.; Lettenmaier, D.P. Potential impacts of a warming climate on water availability in snow-dominated regions. Nature 2005, 438, 303-309.

2. Arendt, A.; Walsh, J.; Harrison, W. Changes of glaciers and climate in northwestern North America during the late twentieth century. J. Clim. 2009, 22, 4117-4134.

3. Willis, M.J.; Melkonian, A.K.; Pritchard, M.E.; Ramage, J.M. Ice loss rates at the Northern Patagonian Ice Field derived using a decade of satellite remote sensing. Remote Sens. Environ. 2012, 117, 184-198. 
4. Willis, M.J.; Melkonian, A.K.; Pritchard, M.E.; Rivera, A. Ice loss from the Southern Patagonia Ice Field, South America, between 2000 and 2012. Geophys. Res. Lett. 2012, 39, L17501. doi: 10.1029/2012GL053136.

5. Molnia, B.F. Glaciers of North America-Glaciers of Alaska. In Satellite Image Atlas of Glaciers of the World; Williams, R.S., Jr., Ferrigno, J.G., Eds.; USGS Professional Paper 1386-K; US Department of the Interior: Washington, DC, USA, 2008; p. 525.

6. Molnia, B.F. Late nineteenth to early twenty-first century behavior of Alaska glaciers as indicators of changing regional climate. Glob. Planet. Chang. 2007, 56, 23-56.

7. Arendt, A.; Echelmeyer, K.A.; Harrison, W.D.; Lingle, C.S.; Valentine, V.B. Rapid wastage of Alaska glaciers and their contribution to rising sea level. Science 2002, 297, 382-386.

8. Berthier, E.; Schiefer, E.; Clarke, G.K.C.; Menounos, B.; Remy, F. Contribution of Alaskan glaciers to sea-level rise derived from satellite imagery. Nat. Geosci. 2010, 3, 92-95.

9. Neal, E.G.; Hood, E.; Smikrud, K. Contribution of glacier runoff to freshwater discharge into the Gulf of Alaska. Geophys. Res. Lett. 2010, doi: 10.1029/2010GL042385.

10. Rignot, E.; Rivera, A.; Casassa, G. Contribution of the Patagonia Icefields of South America to sea level rise. Science 2003, 302, 434-437.

11. Davies, B.J.; Glasser, N.F. Accelerating shrinkage of Patagonia glaciers from the Little Ice Age ( AD1870) to 2011. J. Glaciol. 2012, 58, 1063-1084.

12. Rivera, A.; Benham, T.; Casassa, G.; Bamber, J.; Dowdeswell, J.A. Ice elevation and areal changes of glaciers from the Northern Patagonia Icefield, Chile. Glob. Planet. Chang. 2007, 59, 126-137.

13. Rosenbluth, B.; Fuenzalida, H.A.; Aceituno, P. Recent temperature variations in southern South America. Int. J. Climatol. 1996, 17, 67-85.

14. Jones, P.D.; Lister, D.H.; Osborn, T.J.; Harpham, C.; Salmon, M.; Morice, C.P. Hemispheric and large-scale land-surface air temperature variations: An extensive revision and an update to 2010. J. Geophys. Res. 2012, doi: 10.1029/2011JD017139.

15. Rasmussen, L.A.; Conway, H.; Raymond, C.F. Influence of upper air conditions on the Patagonia Icefields. Glob. Planet. Chang. 2007, 59, 203-216.

16. Glasser, N.F.; Harrison, S.; Jansson, K.N.; Anderson, K.; Cowley, A. Global sea-level contribution from the Patagonia Icefields since the Little Ice Age maximum. Nat. Geosci. 2011, 4, 303-307.

17. Chen, J.L.; Wilson, C.R.; Tapley, B.D.; Blankenship, D.D.; Ivins, E.R. Patagonia Icefield melting observed by Gravity Recovery and Climate Experiment (GRACE). Geophys. Res. Lett. 2007, doi: 10.1029/2007GL031871,

18. Jacob, T.; Wahr, J.; Pfeffer, W.T.; Swenson, S. Recent contributions of glaciers and ice caps to sea level rise. Nature 2012, 482, 514-518.

19. Ramage, J.M.; Isacks, B.L. Determination of melt onset and refreeze timing on Southeast Alaskan Icefields using SSM/I diurnal amplitude variations. Ann. Glaciol. 2002, 34, 391-398.

20. Ramage, J.M.; Isacks, B.L. Interannual variations in snow melt and refreeze timing on Southeast Alaskan Glaciers. J. Glaciol. 2003, 49, 102-116. 
21. Kopczynski, S.; Ramage, J.; Lawson, D.; Goetz, S.; Evenson, E.; Denner, J.; Larson, G. Passive microwave (SSM/I) satellite predictions of valley glacier hydrology, Matanuska Glacier, Alaska. Geophys. Res. Lett. 2008, doi: 10.1029/2008GL034615.

22. Monahan, P.A.; Ramage, J.M. AMSR-E melt patterns on the Southern Patagonian Ice Field. J. Glaciol. 2010, 56, 699-708.

23. Armstrong, R.L.; Knowles, K.W.; Brodzik, M.; Hardman, M.A. DMSP SSM/I-SSMIS Pathfinder Daily EASE-Grid Brightness Temperatures, Version 2; NSIDC (National Snow and Ice Data Center): Boulder, CO, USA, 1998.

24. Armstrong, R.; Raup, B.; Khalsa, S.J.S.; Barry, R.; Kargel, J.; Helm, C.; Kieffer, H. GLIMS Glacier Database; NSIDC (National Snow and Ice Data Center): Boulder, CO, USA, 2011.

25. US Geological Survey (USGS). Landsat ETM Plus Pan Sharpened Mosaic; USGS Earth Resources Observation and Science Center: Sioux Falls, SD, USA, 2010.

26. Long, D.; Brabets, T. Coverage YUK_LAND and YUK_DEM National Stream Quality Accounting Network (NASQAN) Yukon River Basin, Canada and Alaska Landcover-Yukon River Basin; US Geological Survey: Anchorage, AK, USA, 2002.

27. Kalnay, E.; Kanamitsu, M.; Kistler, R.; Collins, W.; Deaven, D.; Gandin, L.; Iredell, M.; Saha, S.; White, G.; Woollen, J.; et al. NCEP/NCAR 40-year reanalysis project. Bull. Am. Meteorol. Soc. 1996, 77, 437-470.

28. Carrasco, J.F.; Casassa, G.; Rivera, A. Meteorological and Climatological Aspect of the Southern Patagonia Icefield. In The Patagonia Icefields; Casassa, G., Sepulveda, F., Sinclair, R., Eds.; Kluwer-Plenum: New York, NY, USA, 2002; pp. 29-41.

29. Mesinger, F.; DiMego, G.; Kalnay, E.; Mitchell, K.; Shafran, P.C.; Ebisuzaki, W.; Jovic, D.; Woollen, J.; Rogers, E.; Berbery, E.H.; et al. North American regional reanalysis: A long-term, consistent, high-resolution climate dataset for the North American domain, as a major improvement upon the earlier global reanalysis datasets in both resolution and accuracy. Bull. Am. Meteorol. Soc. 2005, doi: 10.1175/BAMS-87-3-343.

30. Brabets, T.P. Hydrology and Modeling of Flow Conditions at Bridge 339 and Mile 38-43, Copper River Highway, Alaska; USGS Scientific Investigations Report 2012-5153; US Geological Survey: Reston, VA, USA, 2012.

31. Neal, E.G.; Host, R.H. Hydrology, Geomorphology, and Flood Profiles of the Mendenhall River, Juneau, Alaska; USGS Water-Resources Investigations Report 99-4150; US Geological Survey: Reston, VA, USA, 1999.

32. Kim, H.; Manghani, R.; Pappone, L. Baker-Pascua Project, Patagonia, Chile. Available online: https://wikis.uit.tufts.edu/confluence/display/aquapedia/Baker-Pascua+Project,+Patagonia,+Chile (accessed on 12 November 2013).

33. Chile: Dirección General de Aguas of the Ministerio de Obras Pũblicas, Golbierno de Chile. Información Oficial Hidrometeorológica y de Calidad de Aguas en Línea. Available online: snia.dga.cl/BNAConsultas (accessed on 10 December 2013).

34. Moya Quiroga, V.; Mano, A.; Asaoka, Y.; Kure, S.; Udo, K.; Mendoza, J. Snow glacier melt estimation in tropical Andean glaciers using artificial neural networks. Hydrol. Earth Syst. Sci. 2013, 17, 1265-1280. 
35. Shulski, M.; Walsh, J.; Stevens, E.; Thoman, R. Diagnosis of extended cold-season temperature anomalies in Alaska. Mon. Wea. Rev. 2010, 138, 453-462.

(C) 2014 by the authors; licensee MDPI, Basel, Switzerland. This article is an open access article distributed under the terms and conditions of the Creative Commons Attribution license (http://creativecommons.org/licenses/by/3.0/). 